\title{
Profil Kecemasan Matematika dan Motivasi Belajar Matematika Siswa pada Pembelajaran Daring
}

\author{
Khoirunnisa ${ }^{1}$, Syafika Ulfah ${ }^{2}$ \\ ${ }^{1,2}$ Program Studi Pendidikan Matematika, Fakultas Ilmu Pendidikan, Universitas Muhammadiyah Prof Dr. Hamka, \\ Jl. Tanah Merdeka No 20, Jakarta Timur, Indonesia \\ Knisa1605@gmail.com
}

\begin{abstract}
This study aims to determine the level of anxiety and students' motivation to learn mathematics in online learning. This study uses a quantitative approach with a survey method for data collection. The questionnaire consists of 45 statements divided into two parts, namely the mathematics anxiety questionnaire and the mathematics learning motivation questionnaire which are compiled in google form. The sample in this study was 365 students obtained in collaboration with State Junior High Schools in East Jakarta. The valid data were then processed with descriptive statistics using Microsoft Excel 2019. The results showed that from five indicators, indicators of learning activities in mathematics anxiety $(\bar{x}=3,66)$ and indicators of extrinsic motivation $(\bar{x}=4,62)$ obtained highest average. Meanwhile, based on the results of the overall score of mathematics anxiety in online learning, it is at a moderate level $(\bar{x}=2,70)$ and motivation to learn mathematics in online learning is in the high level $(\bar{x}=3,90)$.
\end{abstract}

Keywords: Mathematics Anxiety, Mathematics Learning Motivation, Online Learning

\begin{abstract}
Abstrak
Penelitian bertujuan untuk meninjau tingkat kecemasan dan motivasi belajar siswa terhadap matematika dalam pembelajaran online. Penelitian ini menggunakan pendekatan kuantitatif dengan metode survei untuk pengumpulan data. Kuesioner terdiri dari 45 butir pernyataan terbagi menjadi dua bagian yaitu kuesioner kecemasan matematika dan kuesioner motivasi belajar matematika yang disusun dalam google form. Sampel dalam penelitian ini sebanyak 365 siswa yang diperoleh melalui kerjasama dengan SMP Negeri di Jakarta Timur. Data yang valid kemudian diolah dengan statistik deskriptif menggunakan Microsoft Excel 2019. Hasil penelitian menunjukkan bahwa dari lima indikator, indikator kegiatan belajar dalam kecemasan matematika $(\bar{x}=3,66)$ dan indikator motivasi ekstrinsik $(\bar{x}=$ $4,62)$ memperoleh rata - rata paling tinggi. Sementara itu, berdasarkan hasil skor keseluruhan kecemasan matematika dalam pembelajaran online berada pada tingkat sedang $(\bar{x}=2,70)$ dan motivasi belajar matematika dalam pembelajaran online berada dalam kategori tinggi $(\bar{x}=3,90)$.
\end{abstract}

Kata kunci: Kecemasan Matematika, Motivasi Belajar Matematika, Pembelajaran Daring

Copyright (c) 2021 Khoirunnisa, Syafika Ulfah

$\triangle$ Corresponding author: Khoirunnisa

Email Address: knisa1605@gmail.com (Jl. Tanah Merdeka No 20, Jakarta Timur, Indonesia)

Received 07 July 2021, Accepted 11 July 2021, Published 02 August 2021

\section{PENDAHULUAN}

Kemajuan dalam bidang teknologi mendorong inovasi pembelajaran daring dengan berbagai jenis pendekatan yang terus berkembang pesat di berbagai belahan dunia (Palvia et al., 2018). Di Indonesia, sekolah maupun peserta didik dianggap belum siap untuk menerapkan pembelajaran daring karena fasilitas yang kurang memadai (Fahmi, 2020). Hasil survei oleh Astini (2020) menunjukkan dari 200 responden yang terlibat dalam penelitian hanya 50\% yang memiliki laptop dan $80 \%$ terkendala dengan sinyal yang tidak stabil karena tempat tinggal yang jauh dari perkotaan. Kondisi geografis Indonesia yang merupakan negara kepulauan menjadi tantangan dalam pendistribusian sarana dan prasarana komunikasi dan teknologi (Fahmi, 2020).

Pembelajaran daring dalam situasi normal dapat memberikan pengaruh positif terhadap motivasi belajar siswa karena pembelajaran online merupakan suatu sistem pembelajaran yang baru sehingga tumbuh 
rasa ingin tahu dan semangat untuk belajar dalam kelas online (Ibrahim \& Suardiman, 2014). Akan tetapi, pembelajaran daring di masa pandemi COVID - 19 justru menimbulkan kecemasan untuk sebagian siswa (Oktawirawan, 2020). Konten dalam pembelajaran daring seringkali hanya dijelaskan secara teoritis saja sehingga sedikit kesempatan bagi siswa untuk berlatih dan belajar secara efektif (Dhawan, 2020). Lingkungan yang tidak kondusif hingga koneksi internet yang tidak stabil merupakan hal yang sering sekali dikeluhkan oleh para siswa ketika mengikuti pembelajaran daring (Irawan et al., 2020). Apabila kecemasan terus berlanjut dan tidak ada solusi dikhawatirkan akan membuat siswa tidak mampu mengontrol dirinya sendiri (Suardana \& Simarmata, 2013).

Kecemasan merupakan masalah psikologi yang sering ditemui dalam kegiatan belajar terlebih lagi dalam pembelajaran matematika yang kemudian dikenal dengan kecemasan matematika (Saputra, 2014). Sifat matematika yang abstrak, penuh dengan angka dan rumus membuat matematika seringkali dipandang sebagai pelajaran yang sulit dan menakutkan (Ekawati, 2015). Kecemasan matematika dipandang sebagai respon siswa terhadap situasi dalam pembelajaran matematika ketika merasa tertekan yang kemudian dapat memicu perasaan tidak nyaman yang ditunjukkan baik secara fisik maupun psikologis (Winarso \& Haqq, 2019). Kesulitan dalam berkonsentrasi, mengingat hingga pemecahan masalah merupakan hambatan dalam belajar yang disebabkan oleh hadirnya kecemasan dalam diri (Ekawati, 2015). Sebuah penelitian menemukan terdapat hubungan yang berbanding terbalik antara kecemasan dan motivasi belajar yang artinya ketika tingkat kecemasan rendah maka semakin tinggi tingkat motivasi belajarnya (Vivin, 2019).

Motivasi memiliki kedudukan yang penting dalam membangkitkan semangat belajar siswa (Emda, 2018). Motivasi belajar sangat diperlukan untuk memperoleh hasil belajar yang baik dan maksimal (Azrai et al., 2016). Penelitian sebelumnya menemukan terdapat perbedaan motivasi yang signifikan antara siswa yang mengikuti kelas online dengan kelas tatap muka, siswa yang mengikuti kelas online memiliki motivasi yang lebih rendah daripada siswa yang mengikuti kelas tatap muka (Stark, 2019). Motivasi menjadi satu dari beberapa hal penting yang perlu diperhatikan dalam pembelajaran online (Dhawan, 2020).

Berdasarkan penjelasan di atas, kecemasan dan motivasi belajar siswa terhadap matematika pada pembelajaran daring akan dibahas lebih lanjut dalam penelitian ini. Tujuan dari penelitian ini yaitu sebagai berikut:

1. Mengetahui tingkat kecemasan siswa terhadap matematika dalam pembelajaran daring beserta faktor penyebabnya.

2. Mengetahui tingkat motivasi belajar matematika dalam pembelajaran daring dan faktor pendorongnya.

Hasil dari penelitian ini diharapkan dapat berkontribusi memperkaya penelitian bidang pendidikan khususnya pendidikan matematika pada pembelajaran daring. Bagi guru ataupun orangtua, penelitian ini dapat memberikan gambaran mengenai tingkat kecemasan dan motivasi belajar siswa terhadap matematika pada pembelajaran daring serta faktor yang mempengaruhinya sehingga dapat menjadi bahan evaluasi dalam mempertimbangkan tindakan yang perlu diambil untuk membantu siswa mengatasi masalah kecemasan dan mempertahankan motivasi belajar dalam pembelajaran daring. 


\section{METODE}

Penelitian ini menggunakan pendekatan kuantitatif dengan metode survei untuk meninjau tingkat kecemasan dan motivasi belajar siswa dalam pembelajaran daring. Instrumen dalam penelitian ini berbentuk kuesioner yang sudah pernah digunakan pada penelitian sebelumnya oleh Suren \& Ali Kandemir (2020). Kemudian, pernyataan dalam instrumen tersebut dimodifikasi sesuai dengan situasi pembelajaran daring. Instrumen yang digunakan dalam penelitian ini berbentuk kuesioner yang terbagi menjadi dua bagian yaitu kecemasan matematika dan motivasi belajar matematika dengan 5 poin skala Likert. Tabel 1 menunjukkan interval yang digunakan untuk interpretasi rata - rata hasil kuesioner kecemasan matematika dan motivasi belajar matematika yang menggunakan 5 poin skala Likert (Suren \& Ali Kandemir, 2020).

Tabel 1. Interpretasi Kuesioner

\begin{tabular}{|c|c|}
\hline Mean $(\overline{\boldsymbol{x}})$ & Interpretasi \\
\hline $1,00-1,79$ & Sangat rendah \\
\hline $1,80-2,59$ & Rendah \\
\hline $2,60-3,39$ & Sedang \\
\hline $3,40-4,19$ & Tinggi \\
\hline $4,20-5,00$ & Sangat Tinggi \\
\hline
\end{tabular}

Kuesioner kecemasan matematika yang dikembangkan oleh Şentürk (2010) berisi 22 item yang terbagi dalam lima indikator. Responden dapat memilih satu dari lima jawaban yang tersedia yaitu (1) Tidak pernah cemas, (2) Sedikit cemas, (3) Terkadang cemas, (4) Sering cemas dan (5) Sangat cemas. Tabel 2 menyajikan kisi - kisi dalam instrumen kuesioner kecemasan matematika.

Tabel 2. Kisi - Kisi Kuesioner Kecemasan Matematika

\begin{tabular}{|c|l|l|c|c|}
\hline No & \multicolumn{1}{|c|}{ Indikator } & \multicolumn{1}{|c|}{ Deskripsi } & $\begin{array}{c}\text { Butir } \\
\text { Pernyataan }\end{array}$ & Jumlah \\
\hline 1 & Sikap & $\begin{array}{l}\text { Kecemasan siswa ketika pelajaran } \\
\text { matematika akan dimulai. }\end{array}$ & $1-4$ & 4 \\
\hline 3 & $\begin{array}{l}\text { Percaya diri } \\
\text { Mengetahuan Konten } \\
\text { kemampuan dan keterampilan dirinya sendiri } \\
\text { dalam matematika. }\end{array}$ & $\begin{array}{l}\text { Kecemasan terhadap hal yang berhubungan } \\
\text { dengan matematika seperti geometri, grafik } \\
\text { dan rumus - rumus. }\end{array}$ & $10-13$ & 4 \\
\hline 4 & Kegiatan belajar & $\begin{array}{l}\text { Perasaan cemas ketika melakukan sesuatu } \\
\text { yang dianggap sulit dalam matematika seperti } \\
\text { tidak bisa menyelesaikan masalah hingga } \\
\text { tidak mampu memahami penjelasan guru. }\end{array}$ & $14-17$ & 4 \\
\hline 5 & Ujian & $\begin{array}{l}\text { Kecemasan menghadapi situasi tertentu yang } \\
\text { berhubungan dengan ujian mulai dari } \\
\text { persiapan sebelum ujian sampai pengumuman } \\
\text { hasil ujian. }\end{array}$ & $18-22$ & 5 \\
\hline
\end{tabular}

Kuesioner motivasi belajar matematika sebanyak 23 item yang diadaptasi oleh Aktan \& Tezci, (2013) 
dari Pintrinch et al (1991) yang terbagi dalam lima indikator. Responden dapat memilih satu dari lima jawaban yang tersedia yaitu (1) Sangat tidak setuju, (2) Tidak setuju, (3) Netral, (4) Setuju dan (5) Sangat setuju. Tabel 3 menyajikan kisi - kisi kuesioner motivasi belajar matematika.

Tabel 3. Kisi - Kisi Kuesioner Motivasi Belajar Matematika

\begin{tabular}{|c|l|l|c|c|}
\hline No & Indikator & \multicolumn{1}{|c|}{ Deskripsi } & $\begin{array}{c}\text { Butir } \\
\text { Pernyataan }\end{array}$ & Jumlah \\
\hline 1 & $\begin{array}{l}\text { Motivasi } \\
\text { Intrinsik }\end{array}$ & $\begin{array}{l}\text { Dorongan dari dalam diri siswa yang tumbuh secara } \\
\text { alami tanpa ada pengaruh dari luar seperti perasaan } \\
\text { bahagia ketika belajar matematika hingga keinginan } \\
\text { untuk terus berjuang meskipun sulit. }\end{array}$ & $1-3$ & 3 \\
\hline 2 & $\begin{array}{l}\text { Motivasi } \\
\text { Ekstrinsik }\end{array}$ & $\begin{array}{l}\text { Siswa semakin terpacu untuk belajar matematika ketika } \\
\text { ada dorongan selain dari dirinya sendiri seperti nilai, } \\
\text { orangtua dan teman. }\end{array}$ & $4-7$ & 4 \\
\hline 3 & Nilai Tugas & Sudut pandang siswa terhadap pelajaran matematika. & $8-12$ & 5 \\
\hline 4 & Keyakinan & $\begin{array}{l}\text { Keyakinan siswa bahwa dirinya sendiri adalah penentu } \\
\text { keberhasilan dalam belajar matematika. }\end{array}$ & $13-17$ & 5 \\
\hline 5 & Efikasi Diri & $\begin{array}{l}\text { Siswa percaya bahwa dengan kemampuan yang } \\
\text { dimilikinya, ia bisa berhasil dalam matematika. }\end{array}$ & $18-23$ & 6 \\
\hline & \multicolumn{1}{|c|}{ Jumlah Pernyataan } & 23 \\
\hline
\end{tabular}

Instrumen yang sudah diterjemahkan ke dalam Bahasa Indonesia kemudian divalidasi oleh ahli. Validasi instrumen dilakukan oleh dua orang ahli yaitu ahli bahasa dan ahli dalam matematika. Hasil validasi ahli menunjukkan beberapa butir perlu diperbaiki. Instrumen yang telah diperbaiki sesuai saran dari validator selanjutnya disusun dalam google form untuk disebarkan kepada subjek penelitian. Populasi dalam penelitian ini adalah siswa SMP Negeri kelas VIII di wilayah Jakarta Timur pada tahun ajaran 2020/2021. Populasi siswa SMP Negeri di Jakarta Timur pada tahun 2020 berjumlah 76.767 (BPS, 2020). Berdasarkan data tersebut maka diperkirakan jumlah populasi siswa SMP Negeri kelas VIII di wilayah Jakarta Timur tahun ajaran 2020/2021 berjumlah 25.589. Formula Estok Nevitte Cowan (2002) digunakan untuk menghitung banyaknya anggota sampel yang secara ideal dapat mewakili keseluruhan populasi (representatif). Pada tahun ajaran 2020/2021 estimasi jumlah populasi (N) adalah 25.589 siswa dan proporsi populasi (P) 33,33\% atau 0,3333 dengan batasan error (E) sebesar 5\%. Berdasarkan perhitungan Formula Estok Nevitte Cowan (2002) dibutuhkan minimal 339 sampel untuk memperoleh sampel yang representatif.

Pengumpulan data dilakukan secara online dengan bantuan google form. Data yang terkumpul dari google form yang telah disebarluaskan kemudian disortir, beberapa data perlu dihapus karena ditemukan satu siswa mengisi kuesioner lebih dari satu kali dan sebagian responden tidak mengisi identitas sesuai dengan yang diperintahkan. Hasil penyortiran data menunjukkan pengisian kuesioner yang dilakukan 365 siswa dinyatakan valid. Selanjutnya, data yang valid diolah dengan statistik deskriptif menggunakan software Microsoft Excel 2019. 


\section{HASIL DAN DISKUSI}

\section{Hasil}

Data yang diperoleh dari responden dianalisis dengan statistik deskriptif untuk mengetahui tingkat kecemasan dan motivasi belajar siswa terhadap matematika pada pembelajaran daring. Hasil statistik deksriptif yang diperoleh dari skor kuesioner kecemasan matematika disajikan dalam tabel 4.

Tabel 4. Analisis Deskriptif Kecemasan Matematika

\begin{tabular}{|c|l|c|c|c|}
\hline No & \multicolumn{1}{|c|}{ Indikator } & Mean $(\overline{\boldsymbol{x}})$ & Simpangan Baku & Interpretasi \\
\hline 1 & Sikap & 1,87 & 1,01 & Rendah \\
\hline 2 & Percaya diri & 2,64 & 1,30 & Sedang \\
\hline 3 & Pengetahuan Konten Matematika & 2,30 & 1,13 & Sedang \\
\hline 4 & Kegiatan belajar & 3,66 & 1,19 & Tinggi \\
\hline 5 & Ujian & 3,00 & 1,42 & Sedang \\
\hline \multicolumn{2}{|l|}{ Keseluruhan Kecemasan Matematika } & 2,70 & 1,36 & Sedang \\
\hline
\end{tabular}

Berdasarkan tabel 4 , indikator kegiatan belajar $(\bar{x}=3,66)$ menjadi indikator yang memperoleh nilai rata - rata paling tinggi, hasil ini menunjukkan bahwa kecemasan matematika pada indikator kegiatan belajar termasuk tingkat tinggi. Pernyataan yang dimuat dalam indikator kegiatan belajar terkait perasaan siswa ketika menghadapi situasi yang dianggap sulit seperti memecahkan masalah, mengingat dan memahami pelajaran. Hasil ini berarti siswa merasa cemas ketika berhadapan dengan situasi saat belajar matematika yang dianggapnya sulit. Sementara itu, secara keseluruhan kecemasan matematika $(\bar{x}=2,70)$ siswa SMP dalam pembelajaran online termasuk dalam kategori sedang.

Tabel 5. Analisis Deskriptif Motivasi Belajar Matematika

\begin{tabular}{|c|l|c|c|c|}
\hline No & \multicolumn{1}{|c|}{ Indikator } & Mean $(\overline{\boldsymbol{x}})$ & Simpangan Baku & Interpretasi \\
\hline 1 & Motivasi Intrinsik & 3,63 & 1,02 & Tinggi \\
\hline 2 & Motivasi Ekstrinsik & 4,62 & 0,73 & Sangat Tinggi \\
\hline 3 & Nilai Tugas & 3,62 & 1,01 & Tinggi \\
\hline 4 & Keyakinan & 4,24 & 0,86 & Sangat Tinggi \\
\hline 5 & Efikasi Diri & 3,51 & 1,05 & Tinggi \\
\hline \multicolumn{2}{|l}{ Keseluruhan Motivasi Belajar Matematika } & 3,90 & 1,04 & Tinggi \\
\hline
\end{tabular}

Tabel 5 menunjukkan hasil analisis deskriptif yang diperoleh dari skor dalam kuesioner motivasi belajar matematika. Berdasarkan tabel 5 , motivasi ekstrinsik $(\bar{x}=4,62)$ adalah indikator dengan rata - rata yang paling tinggi dibandingkan dengan indikator lainnya. Pernyataan yang dimuat dalam indikator motivasi ekstrinsik terkait dengan dorongan dari luar yang membuat seorang individu ingin belajar matematika seperti nilai, dukungan dan pengakuan dari orang lain. Hasil tersebut sejalan dengan penelitian Stark (2019) yang menemukan motivasi ektrinsik menjadi indikator dengan perolehan rata - rata tertinggi dibanding yang lainnya. Akan tetapi, hasil penemuan Bonito (2013) menunjukkan motivasi ekstrinsik berada pada tingkat sedang. Sementara itu, berdasarkan skor keseluruhan tingkat motivasi belajar matematika siswa $(\bar{x}=3,90)$ dalam pembelajaran online termasuk kategori tinggi. 


\section{Diskusi}

Indikator kegiatan belajar dalam kuesioner kecemasan matematika memperoleh rata - rata paling tinggi. Kecemasan matematika berkaitan dengan penilaian seorang individu terhadap dirinya, individu yang menilai kemampuan matematikanya rendah maka cenderung merasa lebih cemas (Dowker et al., 2016). Siswa dengan gangguan kecemasan berlebih cenderung memiliki pandangan negatif yang dapat memberikan pengaruh buruk terhadap motivasi belajarnya (Vivin, 2019). Panik, putus asa hingga stress merupakan bentuk dari efek negatif yang mungkin timbul ketika seorang individu dengan gangguan kecemasan matematika dituntut untuk memecahkan masalah matematika (Syafri, 2017).

Berdasarkan skor keseluruhan, kecemasan matematika siswa dalam pembelajaran online berada pada tingkat sedang. Kecemasan dan kemampuan matematika memiliki hubungan yang berbanding terbalik (Syafri, 2017; Wang et al., 2015). Merujuk pada pernyataan tersebut berarti individu dengan kecemasan matematika yang rendah memiliki kemampuan yang baik dalam matematika begitupun sebaliknya. Kecemasan matematika mempengaruhi prestasi dan kemampuan siswa maka guru harus berusaha untuk memahaminya dan menerapkan strategi dan kebiasaan belajar yang dapat membantu mereka mengatasi kecemasan (Mutodi \& Ngirande, 2014).

Motivasi ekstrinsik menjadi indikator yang memperoleh rata - rata paling tinggi dibandingkan dengan indikator lainnya. Motivasi ekstrinsik mencakup dorongan dari orangtua, kompetensi pengajar, sarana prasarana dan interaksi sosial (Tokan \& Imakulata, 2019). Fakta yang ditemukan di lapangan motivasi ekstrinsik lebih mendominasi dikalangan siswa yang artinya minat untuk belajar sangat dipengaruhi oleh lingkungannya (Suprihatin, 2015). Lingkungan merupakan faktor ekstrinsik yang dapat mempengaruhi tumbuhnya motivasi seseorang individu (Emda, 2018). Dengan demikian, dapat disimpulkan motivasi ekstrinsik merupakan faktor utama yang mendorong siswa dalam belajar matematika. Oleh karena itu, diperlukan adanya lingkungan yang mampu memberikan dukungan seperti menyediakan fasilitas belajar yang memadai, mengapresiasi hasil kerja ataupun memberikan rewards.

Secara keseluruhan motivasi belajar matematika siswa pada pembelajaran online termasuk dalam kategori tinggi. Hasil ini didukung penelitian sebelumnya yang menemukan bahwa sebagian besar siswa SMP memiliki motivasi belajar yang baik dalam pembelajaran online (Alifia \& Pradipta, 2021). Keberhasilan seorang siswa dalam kegiatan belajar dipengaruhi motivasi belajar (Emda, 2018). Motivasi belajar dan hasil belajar memiliki hubungan yang positif berarti semakin rendah motivasi maka hasil belajarnya pun akan ikut menurun seiring dengan penurunan motivasinya (Warti, 2018). Oleh karena itu, sangatlah penting untuk menjaga motivasi belajar siswa karena motivasi belajar siswa berpengaruh terhadap hasil belajarnya.

\section{KESIMPULAN}

Hasil penelitian menunjukkan bahwa kegiatan belajar $(\bar{x}=3,66)$ menjadi indikator dengan rata rata paling tinggi dan ini termasuk dalam kategori tinggi. Pernyataan yang dimuat dalam indikator kegiatan belajar terkait perasaan siswa ketika menghadapi situasi yang dianggap sulit seperti memecahkan masalah, 
mengingat dan memahami pelajaran. Hasil ini mengindikasikan bahwa kesulitan yang dihadapi siswa ketika belajar matematika menjadi faktor penyebab kecemasan matematika. Sementara itu, berdasarkan skor keseluruhan tingkat kecemasan matematika siswa $(\bar{x}=2,70)$ dalam pembelajaran online berada pada tingkat sedang. Indikator dalam motivasi belajar matematika yang memperoleh rata - rata tertinggi yaitu motivasi ekstrinsik $(\bar{x}=4,62)$ dalam kategori sangat tinggi. Maka dari itu, siswa sangat membutuhkan hadirnya dorongan dari luar seperti dukungan teman, guru ataupun orangtua untuk membuatnya lebih semangat dalam belajar matematika. Berdasarkan skor keseluruhan, tingkat motivasi belajar matematika $(\bar{x}=3,90)$ dalam pembelajaran daring termasuk dalam kategori tinggi. Hasil tersebut menunjukkan siswa memiliki semangat untuk belajar matematika yang tinggi dalam pembelajaran daring. Penelitian selanjutnya dapat dilakukan adalah menemukan faktor lain yang dapat menyebabkan kecemasan matematika dan faktor yang memotivasi belajar matematika.

\section{REFERENSI}

Aktan, S., \& Tezci, E. (2013). Matematik Motivasyon Ölçegi (MMÖ) Geçerlik Ve Güvenirlik Çalismasi [The Mathematical Motivation Scale (MMS) Study of Reliability and Validity]. The Journal of Academic Social Science Studies, Volume 6 I(6), 57-77. https://doi.org/10.9761/JASSS1173

Alifia, Z., \& Pradipta, T. R. (2021). Analisis Motivasi Belajar Matematika Siswa dalam Penerapan Edmodo di Masa Pandemi COVID-19. Jurnal Cendekia: Jurnal Pendidikan Matematika, 5(2). https://doi.org/10.31004/cendekia.v5i2.591

Astini, N. K. S. (2020). Tantangan Dan Peluang Pemanfaatan Teknologi Informasi Dalam Pembelajaran Online Masa Covid-19. Cetta: Jurnal Ilmu Pendidikan, 3(2), 241-255. https://doi.org/10.37329/cetta.v3i2.452

Azrai, E. P., Evriyani, D., \& Prastya, A. R. (2016). Hubungan Tingkat Kecemasan Siswa dalam Menghadapi Tes dengan Tingkat Motivasi Belajar Biologi pada Siswa Kelas X Mia SMA Negeri 21 Jakarta. BIOSFER: JURNAL PENDIDIKAN BIOLOGI, 9(1), 47-54. https://doi.org/10.21009/biosferjpb.9-1.8

Bonito, S. R. (2013). Motivation Factors in Distance Education. World Academy of Science, Engineering and Technology, 7(2). https://doi.org/https://doi.org/10.5281/zenodo.1077191

BPS. (2020). Jumlah Sekolah, Guru, dan Murid Sekolah Menengah Pertama (SMP) di Bawah Kementerian Pendidikan dan Kebudayaan Menurut Kabupaten/Kota di Provinsi DKI Jakarta 2017-2020. https://jakarta.bps.go.id/indicator/28/734/1/jumlah-sekolah-guru-dan-murid-sekolah-menengahpertama-smp-di-bawah-kementerian-pendidikan-dan-kebudayaan-menurut-kabupaten-kota-diprovinsi-dki-jakarta-2017-2018-.html

Dhawan, S. (2020). Online Learning: A Panacea in the Time of COVID-19 Crisis. Journal of Educational Technology Systems, 49(1), 5-22. https://doi.org/10.1177/0047239520934018

Dowker, A., Sarkar, A., \& Looi, C. Y. (2016). Mathematics anxiety: What have we learned in 60 years? In Frontiers in Psychology (Vol. 7, Issue APR). https://doi.org/10.3389/fpsyg.2016.00508

Ekawati, A. (2015). Pengaruh Kecemasan Terhadap Hasil Belajar Matematika Siswa Kelas VII Smpn 13 Banjarmasin. Math Didactic: Jurnal Pendidikan Matematika, 1(3), 164-169. https://doi.org/10.33654/math.v1i3.16

Emda, A. (2018). Kedudukan Motivasi Belajar Siswa dalam Pembelajaran. Lantanida Journal, 5(2). https://doi.org/10.22373/lj.v5i2.2838

Fahmi, M. H. (2020). Komunikasi Synchronous dan Asynchronous dalam E-Learning pada Masa Pandemic Covid-19. Jurnal Nomosleca, 6(2). https://doi.org/10.26905/nomosleca.v6i2.4947 
Ibrahim, D. S., \& Suardiman, S. P. (2014). Pengaruh Penggunaan E-Learning terhadap Motivasi dan Prestasi Belajar Matematika Siswa SD Negeri Tahunan Yogyakarta. Jurnal Prima Edukasia, 2(1), 66. https://doi.org/10.21831/jpe.v2i1.2645

Irawan, A. W., Dwisona, D., \& Lestari, M. (2020). Psychological Impacts of Students on Online Learning During the Pandemic COVID-19. KONSELI: Jurnal Bimbingan Dan Konseling (E-Journal), 7(1). https://doi.org/10.24042/kons.v7i1.6389

Mutodi, P., \& Ngirande, H. (2014). Exploring Mathematics Anxiety: Mathematics Students' Experiences. Mediterranean Journal of Social Sciences, 5(1). https://doi.org/10.5901/mjss.2014.v5n1p283

Oktawirawan, D. H. (2020). Faktor Pemicu Kecemasan Siswa dalam Melakukan Pembelajaran Daring di Masa Pandemi Covid-19. Jurnal Ilmiah Universitas Batanghari Jambi, 20(2), 541-544. https://doi.org/10.33087/jiubj.v20i2.932

Palvia, S., Aeron, P., Gupta, P., Mahapatra, D., Parida, R., Rosner, R., \& Sindhi, S. (2018). Online Education: Worldwide Status, Challenges, Trends, and Implications. In Journal of Global Information Technology Management (Vol. 21, Issue 4). https://doi.org/10.1080/1097198X.2018.1542262

Saputra, P. R. (2014). Kecemasan Matematika dan Cara Menguranginya (Mathematic Anxiety and How To $\begin{array}{lllll}\text { Reduce It } & \text { It Jurnal }\end{array}$ https://www.journal.unrika.ac.id/index.php/jurnalphythagoras/article/view/590/451

Şentürk, B. (2010). İlköğretim beşinci sinif öğrencilerinin genel başarilari, matematik başarilari, matematik dersine yönelik tutumlari ve matematik kaygilari arasindaki ilişki [The Relationship between Fifth-grade Students' General Achievement, Mathematics A [Afyon Kocatepe Üniversitesi]. http://hdl.handle.net/11630/3135

Stark, E. (2019). Examining the Role of Motivation and Learning Strategies in the Success of Online vs. Face-to-Face Students. Online Learning, 23(3). https://doi.org/10.24059/olj.v23i3.1556

Suardana, A. A. P. C. P., \& Simarmata, N. (2013). Hub Motivasi Belajar Dan Kecemasan Menjelang Ujian. Jurnal Psikologi Udayana, 203-212. https://doi.org/https://doi.org/10.24843/JPU.2013.v01.i01.p20

Suprihatin, S. (2015). Upaya Guru dalam Meningkatkan Motivasi Belajar Siswa. PROMOSI (Jurnal Pendidikan Ekonomi), 3(1). https://doi.org/10.24127/ja.v3i1.144

Suren, N., \& Ali Kandemir, M. (2020). The effects of mathematics anxiety and motivation on students' mathematics achievement. International Journal of Education in Mathematics, Science and Technology, 8(3), 190-218. https://doi.org/10.46328/IJEMST.V8I3.926

Syafri, F. S. (2017). Ada Apa Dengan Kecemasan Matematika? Journal of Medives, 1(1), 59-65. http://ejournal.ikip-veteran.ac.id/index.php/matematika

Tokan, M. K., \& Imakulata, M. M. (2019). The effect of motivation and learning behaviour on student achievement. South African Journal of Education, 39(1). https://doi.org/10.15700/saje.v39n1a1510

Vivin, V. (2019). Kecemasan dan motivasi belajar. Persona:Jurnal Psikologi Indonesia, 8(2), 240-257. https://doi.org/10.30996/persona.v8i2.2276

Wang, Z., Lukowski, S. L., Hart, S. A., Lyons, I. M., Thompson, L. A., Kovas, Y., Mazzocco, M. M. M., Plomin, R., \& Petrill, S. A. (2015). Is Math Anxiety Always Bad for Math Learning? The Role of Math Motivation. Psychological Science, 26(12). https://doi.org/10.1177/0956797615602471

Warti, E. (2018). Pengaruh Motivasi Belajar Siswa terhadap Hasil Belajar Matematika Siswa di SD Angkasa 10 Halim Perdana Kusuma Jakarta Timur. Mosharafa: Jurnal Pendidikan Matematika, 5(2), 177-185. https://doi.org/10.31980/mosharafa.v5i2.273

Winarso, W., \& Haqq, A. A. (2019). Psichological disposition of student; Mathematics anxiety vesus happines learning on the level education. International Journal of Trends in Mathematics Education Research, 2(1), 19. https://doi.org/10.33122/ijtmer.v2i1.32. 